$1-1-1964$

\title{
Sheep production : costs and returns in West Virginia
}

Alfred L. Barr

Follow this and additional works at: https://researchrepository.wvu.edu/ wv_agricultural_and_forestry_experiment_station_bulletins

\section{Digital Commons Citation}

Barr, Alfred L., "Sheep production : costs and returns in West Virginia" (1964). West Virginia Agricultural and Forestry Experiment Station Bulletins. 495.

https://researchrepository.wvu.edu/wv_agricultural_and_forestry_experiment_station_bulletins/463 @ WVU. It has been accepted for inclusion in West Virginia Agricultural and Forestry Experiment Station Bulletins by an authorized administrator of The Research Repository @WVU. For more information, please contact ian.harmon@mail.wvu.edu. 


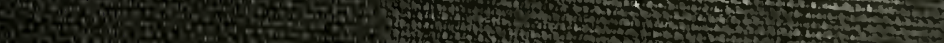

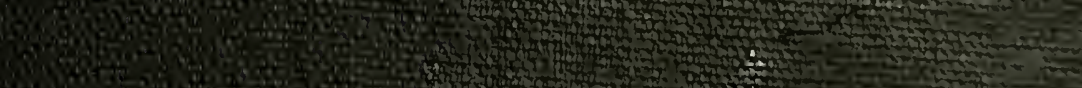

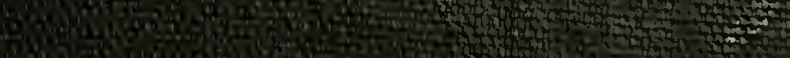

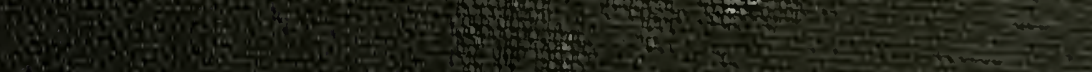
9. N0.0.

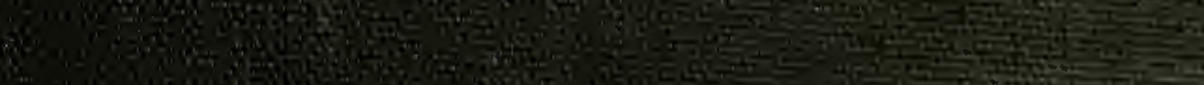

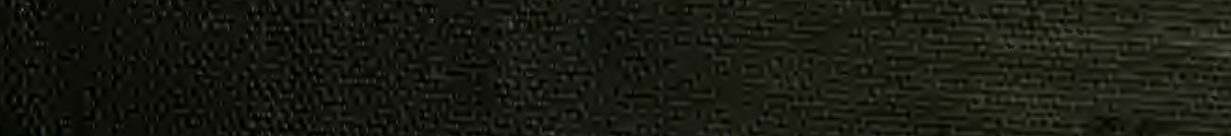

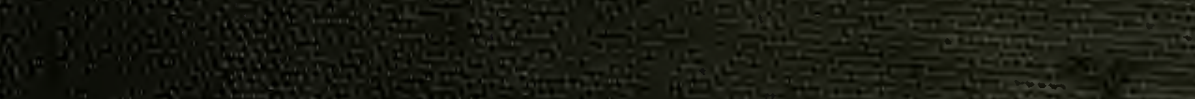

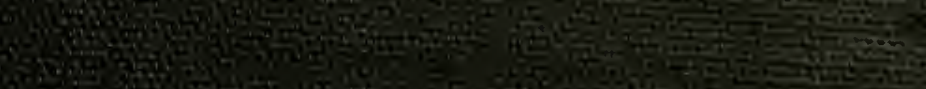

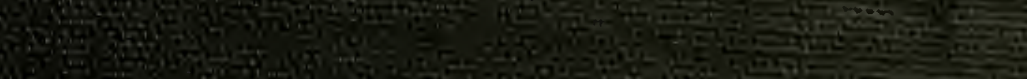

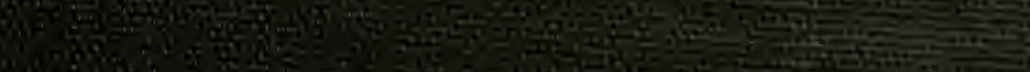
Wo 4.

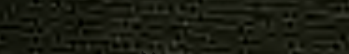
19: 8.

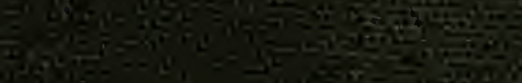


Digitized by the Internet Archive in 2010 with funding from Lyrasis Members and Sloan Foundation 


\section{THE AUTHORS}

Authors of Sheep Production-Costs and Returns in West Virginia are Alfred L. Barr, Associate Agricultural Economist; James A. Welch, Animal Husbandman; John Rosenberger, Associate County Agricultural Agent, Juniata County, Pennsylvania; and B. W. Wamsley, Jr., State Extension Animal Husbandry Specialist, Cooperative Extension Service.

WEST VIRGINIA UNIVERSITY

Agrigultural Experiment Station

College of Agriculture, Forestry, and Home Economics

A. H. Vanlandingham, Director

MORGANTOWN 


\section{Contents}

INTRODUCTION $\ldots \ldots \ldots \ldots \ldots \ldots \ldots \ldots \ldots \ldots \ldots \ldots$

PART 1: MASTER SHEPHERD'S PROJECT DATA ..... 5

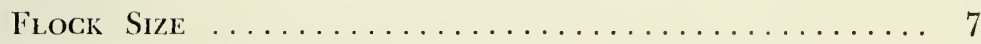

Lanib Mortality ..................... 8

Per Cent Lamb Crop Marketed and Kept ......... 9

Weight of LaMis MARKETED AND KePt .......... 9

Grades of Lamiss Marketed $\ldots \ldots \ldots \ldots \ldots \ldots \ldots \ldots, 9$

Weight of Lambs Marketed by Grades ........... 10

WEIGHT OF WoOL $\ldots \ldots \ldots \ldots \ldots \ldots \ldots \ldots \ldots \ldots \ldots \ldots \ldots \ldots$

Returns from Lamiss .................. I2

Return from Wool per Breeding Ewe .......... 19

PART II: DATA OBTAINED BY ESTIMATES ........ I3

Feed Requirements and Costs $\ldots \ldots \ldots \ldots \ldots \ldots \ldots$ I4

Medication Requirements and Costs ........... I4

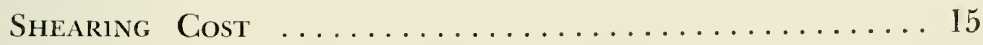

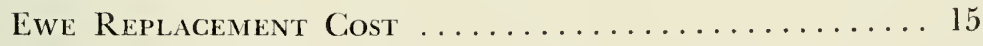

Ram Replacement Cost ................ I5

Marketing $\operatorname{Cost} \ldots \ldots \ldots \ldots \ldots \ldots \ldots \ldots \ldots \ldots$

PART 1II: ANALYSIS OF COSTS AND RETURNS ...... I6

Summary, Conclusions, and Implications ......... 17

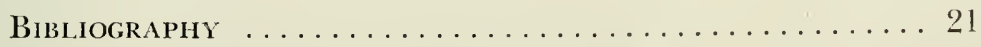

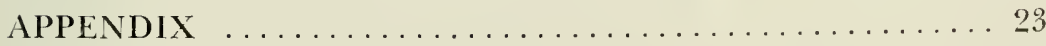





\section{SHEEP PRODUCTION- \\ Costs and Returns in West Virginia}

Alfred L. Barr, James A. Welch, John Rosenberger, and B. W. Wamsley, Jr.

\section{INTRODUCTION}

THE SHEEP POPULATION in West Virginia has been on the decline for several years. In 1954 there were 317,000 sheep and lambs reported on West Virginia farms as compared with 220,000 on farms on January 1, 1964-a 30 per cent reduction in the sheep population for the State $(4,6)$.

Cash income from sheep has also declined in West Virginia during this same period. In 1954, gross receipts from the sale of sheep and lambs were $\$ 3,457,000$ and receipts from wool were $\$ 884,000(6)$. These figures compared with $\$ 2,627,000$ gross income received from the sale of sheep and lambs and $\$ 729,000$ received from the sale of wool in 1961 . The total decline in the major sources of income in the sheep industry --wool, sheep, and lambs-was 22 per cent. In 1954, income from the sheep industry in West Virginia represented 3.6 per cent of the cash receipts from all farm marketings, and had declined to 3.2 per cent in 1961.

This study was designed to determine (1) if sheep are or can be profitable on West Virginia farms and (2) the factors associated with returns from a sheep enterprise.

This report is divided into three parts: I. The data obtained from the farm flock records through the Master Shepherd's Project are summarized and analyzed, and factors associated with high and low returns from the sheep enterprise are identified. II. Estimates of various cost items are presented. Although a large number of records were available, cost data were incomplete. Therefore, it was necessary to estimate some input and cost data. III. The costs and returns are summarized in budget form and estimates are made of the profitability of a sheep enterprise in West Virginia.

\section{PART I: Master Shepherd's Project Data}

The Master Shepherd's Project is sponsored by the Cooperative Extension Service of West Virginia University to stimulate wider use 
of recommended sheep management practices. Farmers desiring to en roll in the program request an application form at their County Agri cultural Extension Agent's office. The completed form is sent to the State Extension Animal Husbandry specialists at West Virginia University. The entry form contains the following information about the farmer's sheep flock: (1) number of ewes bred, (2) breeding dates, (3) breed of ewes in flock, (4) approximate average weight of ewes, and (5) breed of rams.

Each accepted applicant receives a project record book that contains the rules, ${ }^{1}$ feeding and management suggestions, and blanks to be completed and returned to the Extension Animal Husbandry specialist at the University after lambs and wool are sold. These final reports contain the lamb record, wool record, gross income record, feeding record, pasture program, parasite control program, and a description of the water supply, and method of feeding.

In five years (1957-1961), a total of 305 flock records-or an average of 61 records per year-were obtained (Table 1). These records contained data on 15,517 breeding ewes, an average of over 3,100 breeding ewes per year. This is about 1 per cent of the ewes over one year old in West Virginia.

\section{TABLE 1}

Number of Flocks and Breeding Ewes InCluded in THE Study, By Years, 1957-1961

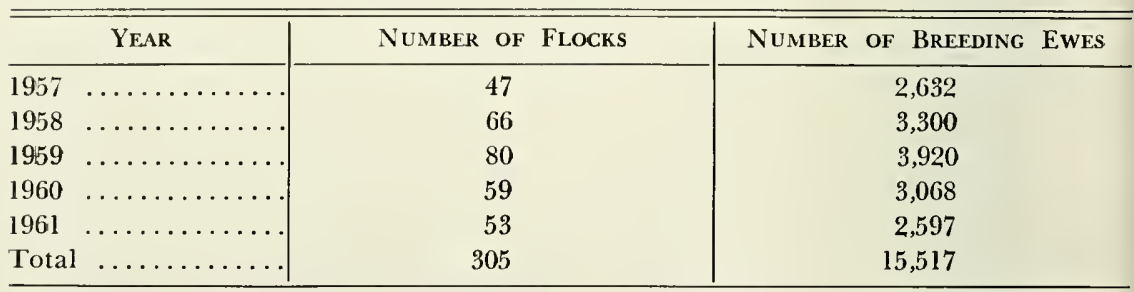

Master Shepherd's Project records were obtained from 24 counties. A majority of the flocks was from the eastern and north central areas of the State. These areas include the major sheep producing counties in West Virginia (Figure 1).

Output data in this study were obtained from the Master Shepherd's Project reports for the years 1957-1961.

For each of the five years the flocks were ranked from high to low on the basis of gross income per breeding ewe. The highest 20 per cent and the lowest 20 per cent of the flocks for each year were then selected

\footnotetext{
${ }^{1}$ Only flocks having 15 or more ewes are accepted in the Master Shepherd's Project Program.
} 


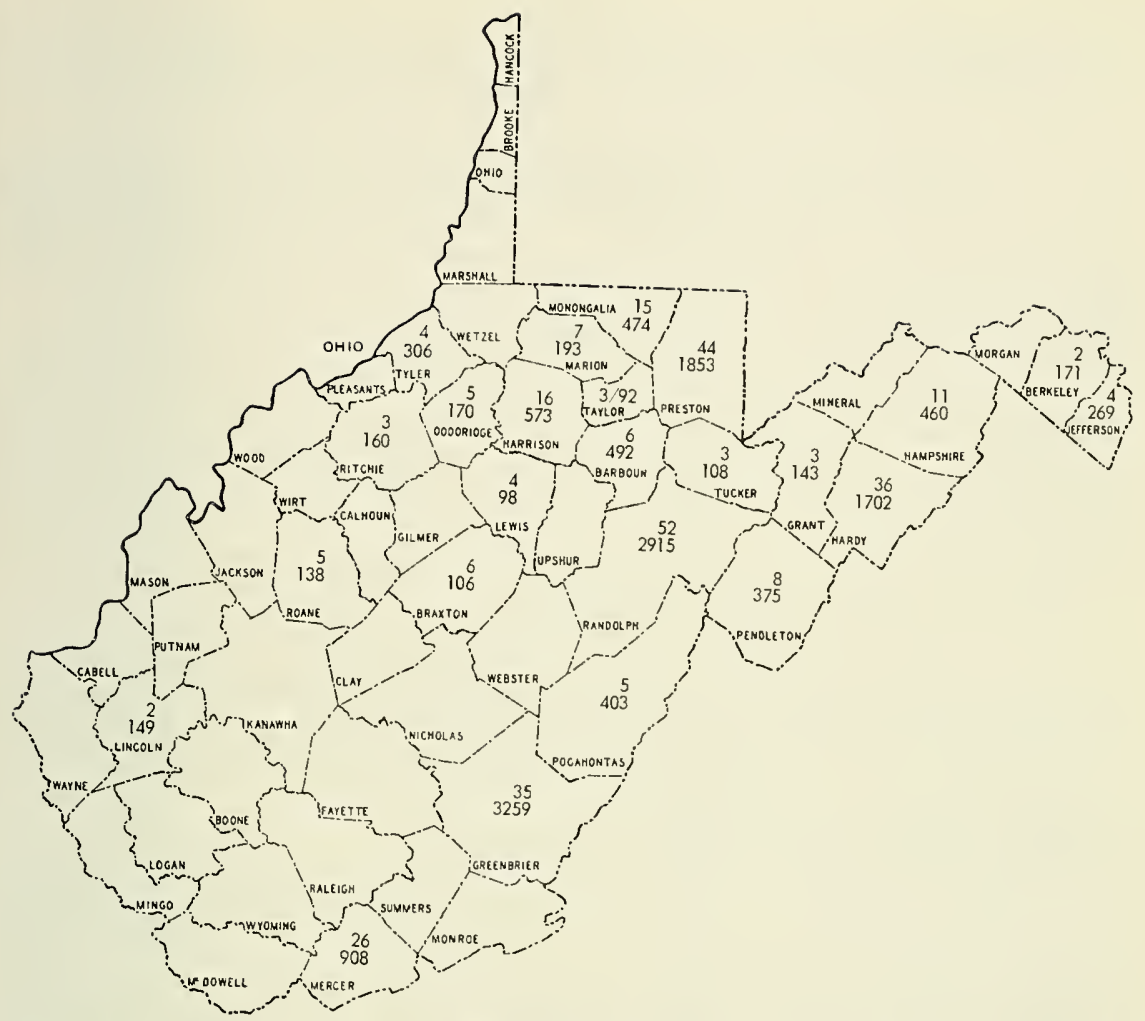

FIGURE 1. Map of West Virginia showing the number of records and the number of ewes by county during the 5-year period, 1957-1961. The top figure represents the number of records obtained per county. The bottom figure represents the number of breeding ewes included in the records obtained.

for comparison with each other and with the average of all flocks. We then attempted to identify factors associated with the high- and lowincome groups. Factors studied were: (1) the number of breeding ewes per flock, (2) per cent mortality of lambs born, (3) per cent lambs marketed and kept for replacement per breeding ewe, (4) weight and grade of lambs marketed, (5) weight of wool marketed per ewe, and (6) price received for lambs and wool sold.

\section{FLOCK SIZE (See Table 2)}

The all-flock average was 51 breeding ewes per flock. The highest income group averaged 44 ewes and the lowest 48 ewes per flock for the five-year study period. Flock size for the high-income group ranged from 17 to 280 ewes, and 15 to 190 ewes for the low-income group. The range for all flocks in the study was from 15 to 330 ewes. 
TABLE 2

Average Number of Breeding Eives Per Flock, Range and Standard Deviation, By Income Groups, 1957-1961

\begin{tabular}{|c|c|c|c|}
\hline \multirow{2}{*}{ YEAR } & \multicolumn{2}{|c|}{20 Per Cent W'ith } & \multirow{2}{*}{ Ale Flocks } \\
\hline & HigheST INCOME & LOWEST INCOME & \\
\hline$\overline{1957}$ & 37 & 39 & $5 \overline{6}$ \\
\hline $1958 \ldots$ & 36 & 52 & 50 \\
\hline $1959 \ldots \ldots \ldots \ldots \ldots$ & 54 & 56 & 49 \\
\hline $1960 \ldots \ldots \ldots \ldots$ & 43 & 47 & 52 \\
\hline $1961 \ldots$ & 44 & 41 & 49 \\
\hline Average...$\ldots \ldots \ldots$ & 44 & 48 & 51 \\
\hline Smallest Flock ...... & 17 & 15 & 15 \\
\hline Largest Flock ....... & 280 & 190 & 330 \\
\hline Standard Deviation* & 37.6 & 33.7 & 44.9 \\
\hline
\end{tabular}

* This is a statistical measure of variation.

Large and small flocks were included in both the highest and lowest income groups in all years. There is no evidence that flock size is associated with income per breeding ewe.

\section{LAMB MORTALITY (See Table 3)}

Nearly 12 per cent of all lambs died or were lost before attaining market weight. Lamb mortality for the five-year period averaged 7 per cent for the highest income group and nearly 19 per cent for the lowest income group. Mortality was calculated by subtracting the number of lambs marketed plus those kept for replacements from the number of lambs born. Lambs slaughtered for home use were reported with the number of lambs marketed or kept for replacement. The causes of the loss of lambs were not reported. Results in this study indicate that the per cent of lamb mortality is a very important factor in determining leve]

TABLE 3

Lamb Mortality, By Income Groups, 1957-1961

\begin{tabular}{|c|c|c|c|}
\hline \multirow{2}{*}{ YEAR } & \multicolumn{2}{|c|}{20 Per Cent With } & \multirow{2}{*}{ AlL Flock: } \\
\hline & Highest INCOME & LOWEST INCOME & \\
\hline 1957 & $\begin{array}{c}\text { Per Cent } \\
6.5\end{array}$ & $\begin{array}{c}\text { Per Cent } \\
14.4\end{array}$ & $\begin{array}{c}\text { Per Cent } \\
9.0\end{array}$ \\
\hline 1958. & 7.1 & 26.7 & 12.3 \\
\hline $1959 \ldots$ & 6.1 & 21.2 & 12.3 \\
\hline $1960 \quad \ldots$ & 8.5 & 24.9 & 12.9 \\
\hline 1961 & 7.1 & 16.9 & 11.8 \\
\hline Average ... & 7.0 & 18.7 & 11.7 \\
\hline
\end{tabular}


of income. Lamb mortality for the lorest income group ranged from 14 per cent (1957) to 27 per cent (1958) but was never over 9 per cent for the highest income group.

\section{PER CENT LAMB CROP MARKETED AND KEPT (See Table 4)}

The per cent lamb crop marketed and kept was determind by dividing the number of lambs marketed plus the lambs kept for replacement by the number of ewes bred. The average lamb crop marketed and kept by all producers over the five-year period was 125 per cent. The high-income group produced a lamb crop of 150 per cent, and the low-income group produced a lamb crop of 96 per cent.

TABLE 4

Lamib Crop Marketed, By Incone Groups, 1957-1961

\begin{tabular}{|c|c|c|c|}
\hline \multirow{2}{*}{ YEAR } & \multicolumn{2}{|c|}{20 Per Cent With } & \multirow{2}{*}{ ALL Flocks } \\
\hline & HIGHEST INCOME & LOWEST INCONE & \\
\hline 1957 & Per Cent & Per Cent & Per Cent \\
\hline $\begin{array}{l}1951 \\
1958\end{array}$ & $\begin{array}{l}103 \\
154\end{array}$ & 81 & $\begin{array}{l}158 \\
118\end{array}$ \\
\hline $1959 \quad$.. & 138 & 95 & 116 \\
\hline $1960 \ldots$ & 142 & 93 & 125 \\
\hline $1961 \ldots$ & 166 & 109 & 133 \\
\hline Average & 150 & 96 & 125 \\
\hline
\end{tabular}

\section{WEIGHT OF LAMBS MARKETED AND KEPT (See Table 5)}

The average weight of lambs produced by all flocks over the fiveyear period was 86 pounds at market time. The lambs produced in the highest income flocks weighed an average of 92 pounds- 6 pounds heavier than the average for all flocks. The lambs produced in the lowest income group averaged 76 pounds. The highest income group not only produced a higher per cent lamb crop than did the low-income group, but the average weight of lambs marketed was also higher. "These two factors together contributed greatly to the difference in income received by the two groups.

\section{GRADES OF LAMBS MARKETED (See Table 6)}

The market grades used when the lambs were marketed, going from high to low quality, were as follows: Blue, Red, Medium, and 
TABLE 5

Average Weight of All Lambs Marketed and Kept, By Income Groups, 1957-1961*

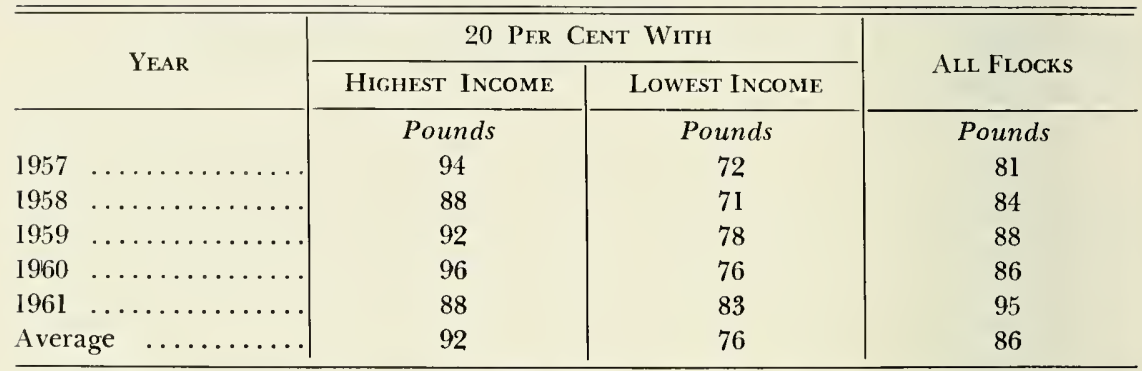

* Data on weights of lambs by grade were reported as a group by each farmer; thus, measures of variation cannot be computed.

Plain. ${ }^{2}$ For convenience, and due to the small number, Medium and Plain lambs were combined and listed as lower grades.

Seventy per cent of the 19,366 lambs graded Blue, 19 per cent graded Red, and about 11 per cent were in the lower grades. The highincome flocks produced a higher percentage of Blue lambs than did the low-income flocks. The highest income group produced 4,002 lambs, of which more than 86 per cent were graded Blue, 11 per cent Red, and only 2 per cent in lower grades. Less than half of the lambs-43 per cent -produced by the lowest income groups graded Blue, 28 per cent graded Red, and the remaining 28 per cent were in the lower grades.

Within a flock one expects twin lambs to weigh less than single lambs. However, despite the fact that more of the lambs marketed by the highest income group were from ewes raising more than one lamb, the lambs' average weight was greater and they graded higher than lambs produced by the average and lowest income group. These factors were important in determining the income per breeding ewe.

\section{WEIGHT OF LAMBS MARKETED BY GRADES (See Table 7)}

A comparison of the average weight of lambs in each grade was made for the high- and low-income flocks as well as for all lambs. Lambs grading Blue and Red were heavier in the highest income flocks than in the lowest income flocks. Blue lambs marketed by the highest income group averaged 93 pounds and Reds averaged 84 pounds-10

${ }^{2}$ The grades Blue, Red, Medium, and Plain compared with U. S. Grades are as follows: U. S. Prime and Choice are Blue, U. S. Good, are Red, U. S. Utility are Mediums, and U. S. Cull are Plain. 


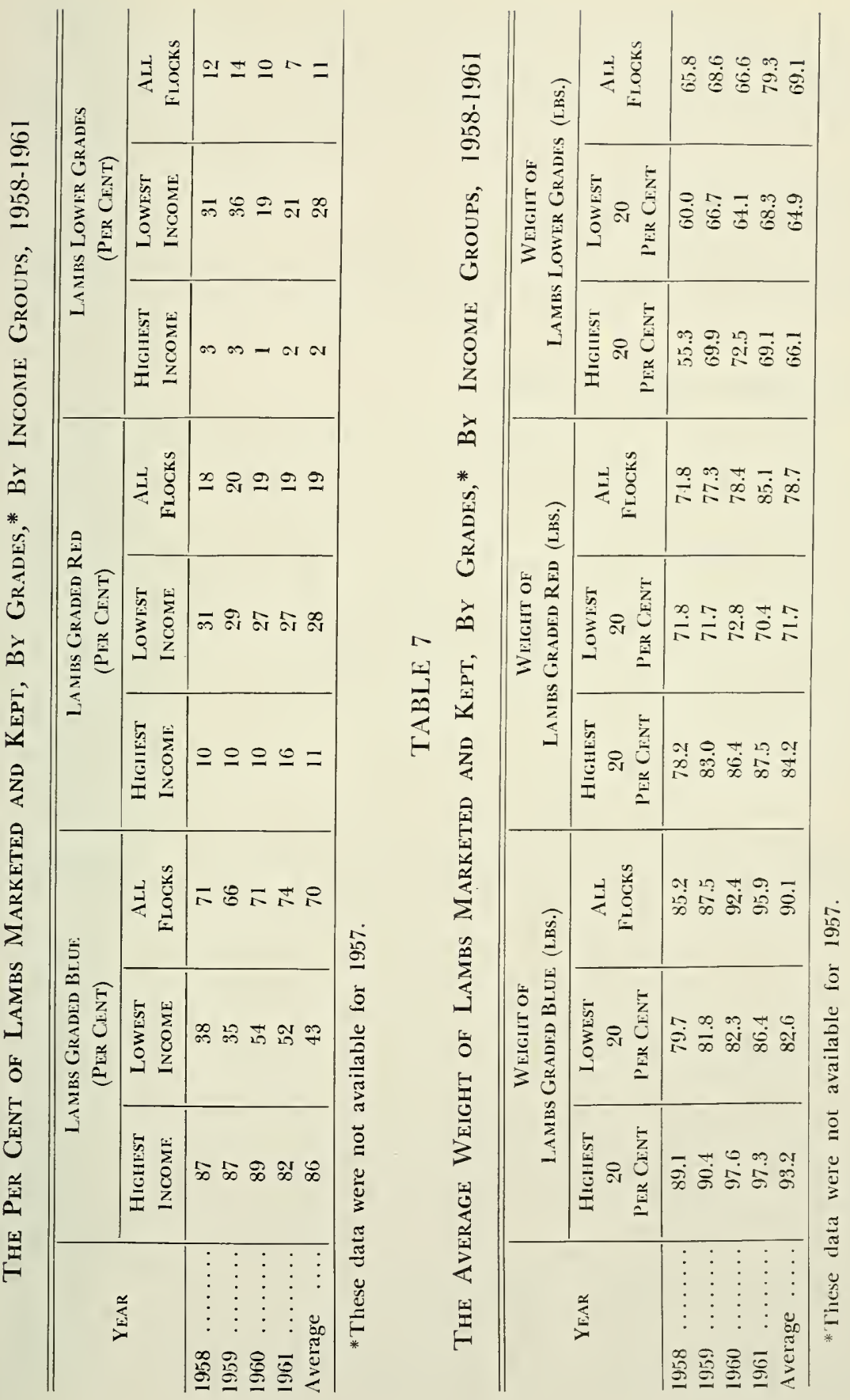


and 12 pounds heavier, respectively, than the corresponding grades of lambs marketed from the lowest income flocks. The average weight of Blue lambs marketed from all flocks over the four-year period for which these data were obtained was 90 pounds; Red lambs averaged 79 pounds, and lambs of the lower grades averaged 69 pounds.

\section{WEIGHT OF WOOL}

The average fleece weight for all ewes was 7 pounds. Differences in the weight of wool and in income received from wool by the three income groups were not large enough to influence income appreciably.

\section{RETURNS FROM LAMBS}

The average income received for lambs, per breeding ewe, in the five-year study was $\$ 21.60$ (Table 8 ). An average of 108 pounds of lamb was produced per breeding ewe. ${ }^{3}$ The weight of lambs kept for replacement was credited to the weight of lambs produced and valued at average Blue grade lamb price. The average value of lambs produced by the highest income flocks was $\$ 29.19$ per breeding ewe. This was about $\$ 7.50$ per ewe above the average return for lambs produced by all the ewes in the study and over $\$ 16.00$ per ewe more than the return received from the lowest income flocks.

\section{TABLE 8}

The Average Pounds of Lamb, Price Per Pound and Income Received from Lambs Per Breeding Ewe, By Income

\section{Groups}

\begin{tabular}{|c|c|c|c|}
\hline & \multicolumn{2}{|c|}{20 Per Cent With } & \multirow{2}{*}{$\begin{array}{c}\text { AlL } \\
\text { FLoCKS }\end{array}$} \\
\hline & $\begin{array}{l}\text { HIGHEST } \\
\text { I NCOME }\end{array}$ & $\begin{array}{l}\text { LOWEST } \\
\text { INCOME }\end{array}$ & \\
\hline $\begin{array}{l}\text { Pounds of Lamb per Ewe .... } \\
\text { Price Received per Pound ... } \\
\text { Income per Ewe from Lambs .. }\end{array}$ & $\begin{array}{l}139 \\
\$ \quad .210 \\
\$ 29.19\end{array}$ & $\begin{array}{r}73 \\
\$ \quad .176 \\
\$ 12.85\end{array}$ & $\begin{array}{r}108 \\
\$ \quad .200 \\
\$ 21.60\end{array}$ \\
\hline
\end{tabular}

The average price received for all lambs over the five-year period was 20 cents per pound (Table 8 ). The highest income group averaged about 21 cents per pound for lambs compared with an average of about 18 cents received by the lowest income group. This difference in price per pound reflects the greater percentage of high-grade lambs marketed by the highest income group.

${ }^{3}$ The average weight of lamb produced per breeding ewe was calculated by multiplying the per cent of lamb crop marketed (Table 4) by the average weight of lambs (Table 5). 


\section{RETURN FROM WOOL PER BREEDING EWE}

Fourteen per cent of the total income received per breeding ewe was from the sale of wool. The highest income group averaged $\$ 3.54$ per ewe from the sale of wool, and the lowest income group averaged $\$ 2.99$ per ewe (Table 9).

Government incentive payment on wool and unshorn lambs sold has provided additional income to the sheep industry in recent years. However, the value of incentive payments are not included in Table 9 because producers submitted their records before incentive payments were received.

\section{TABLE 9}

The Average Weight of Wool, Price Per Pound, and Income Receivfo from Wool, Per Breeding Ewe, By Income Groups

\begin{tabular}{|c|c|c|c|}
\hline & $\begin{array}{l}\text { HIGHEST } \\
\text { INCOME }\end{array}$ & $\begin{array}{l}\text { LOWEST } \\
\text { INCONE }\end{array}$ & $\begin{array}{c}\text { AlL } \\
\text { Flocj́s }\end{array}$ \\
\hline $\begin{array}{l}\text { Pounds of Wool per Ewe . } \\
\text { Price Received per Ponnd* } \\
\text { Income Received from Wool* }\end{array}$ & $\begin{array}{l}7.0 \\
\$ .506 \\
\$ 3.54\end{array}$ & $\begin{array}{l}6.0 \\
\$ .499 \\
\$ 2.99\end{array}$ & $\begin{array}{l}7.0 \\
\$ .514 * * \\
\$ 3.60\end{array}$ \\
\hline
\end{tabular}

* Wool price does not include incentive payment.

**'The variation in price received per pound of wool is largely due to the different channels through which the wool was marketed. Although the better producers probably did a better job of marketing their wool during the years covered by the study, the price they received was lower than the average received by all producers. The lower price received by the lowest income group probably reflects lower quality wool.

\section{PART II: Data Obtained by Estimates}

The input data were not nearly as complete as the output data in the Master Shepherd's Project reports and summaries. For this reason estimates of costs were made for purposes of this study.

The estimates were based on recommendations outlined in the Master Shepherd's Project Book, Field Workers' Blue Book for Livestock Production, and available unpublished data on sheep production costs. Each of the specified input factors was considered as an individual item and a unit value was placed on each. The costs for feed, medication, shearing, ewe and ram replacement, and marketing were estimated. A flock of 50 breeding ewes and 2 rams was used as a basis for making the estimates.

The requirements specified in Table 10 do not include all of the inputs normally required by a sheep enterprise. The additional cost items such as interest, labor, land, buildings, equipment, and management were not estimated. Thus, in the final analysis, the difference be- 
TABLE 10

Estimated Input Requirements Per Breeding Ewe Per Year

\begin{tabular}{|c|c|c|c|c|}
\hline ITEM & UNIT & Number & $\begin{array}{l}\text { Estimated } \\
\text { Price/Unit }\end{array}$ & Cost \\
\hline Concentrate $\ldots \ldots \ldots \ldots \ldots$ & cwt. & 0.75 & $\$ 2.87$ & $\$ 2.15$ \\
\hline$\ldots \ldots \ldots \ldots \ldots \ldots \ldots$ & ton & 0.25 & 33.00 & 8.25 \\
\hline Phenothiazine Mineral Salt & lb. & 6.0 & .108 & .65 \\
\hline Medication (Drench) & - & - & - & .28 \\
\hline Shearing (custom rate) & head & 1.0 & .50 & .50 \\
\hline Ewe Replacement ..... & ewe & 1.0 & 3.08 & 3.08 \\
\hline Ram Replacement ..... & ewe & 1.0 & .67 & .67 \\
\hline Marketing $\ldots \ldots \ldots$ & cwt. & 0.92 & .50 & .46 \\
\hline Total $\ldots \ldots \ldots \ldots$ & & & & I6.04 \\
\hline
\end{tabular}

tween the specified cost and the specified receipts results in a return to labor, capital, ${ }^{*}$ and management.

\section{FEED REQUIREMENTS AND COSTS}

A grain ration consisting of 6 parts of corn, 4 parts of oats, 2 parts of wheat bran, and 1 part of soybean oil meal, plus a liberal amount of good quality alfalfa hay was selected as a basis for estimating feed cost. It was estimated that 75 pounds of the selected grain ration and 500 pounds of hay would be required each year to feed a breeding ewe and her lambs to weaning age. Thus, the average annual estimated cost of feed per breeding ewe was $\$ 8.25$ for hay and $\$ 2.15$ for concentrates. ${ }^{5}$

\section{MEDICATION REQUIREMENTS AND COSTS}

Estimated medication costs for controlling internal parasites of sheep were based on recommendations suggested by the State Extension Animal Husbandry specialists at West Virginia University. ${ }^{6}$ The suggested internal parasite control recommendations included the feeding of a mixture of 7 pounds of steamed bonemeal, 7 pounds of salt, and 1 pound of phenothiazine. Average annual consumption of the phenothiazine and salt mixture was estimated at 6 pounds per ewe. Thus, the average annual estimated cost of phenothiazine-salt was 65 cents

${ }^{4}$ In this study, capital refers to all supplies, land, buildings, equipment, and investment in livestock.

'The concentrate and hay costs were calculated using prices itemized in Appendix Table 2.

${ }^{6}$ Field Workers' Blue Book, Livestock Program, 1962, Controlling Internal Parasites in Sheep, Cooperative Extension Service, W. Va. University, pp. 36-37. (Recent recommendations differ. See W. Va. Agr. Ext. Misc. Pub. No. 129.) 
per breeding ewe.' It was assumed that the ewes would be drenched with phenothiazine three times per year and the lambs twice. The estimated cash cost per treatment was five cents. Thus, the average estimated cost of drenching was 28 cents per breeding ewe per year. ${ }^{8}$

\section{SHEARING COST}

The charge for custom shearing of ewes during the period (19571961) was about 50 cents per head.

\section{EWE REPLACEMENT COST}

A sheep producer should normally cull some ewes each year because of lambing failure, poor mothering ability, age, etc., and there will also be some death losses. For purposes of this analysis, it was estimated that $1 / 6$ of the ewes would be culled or die each year. Thus, a total of 16 ewes of breeding age would die or be culled each year. To maintain a 100-ewe breeding flock 16 ewe lambs would have to be added to the flock each year. To have 16 acceptable lambs for replacement, it probably would be necessary to keep about 18 replacement lambs. If the 18 replacements were valued at 21.5 cents per pound (the average price received for Blue grade lambs) and weighed 95 pounds at market time, their value would be $\$ 20.42$ each or a total of $\$ 367.56$. Ten ewes were assumed to be sold as culls each year. If the culls sell for an average of $\$ 6.00$ they will return $\$ 60.00$. Thus, the annual estimated depreciation (death loss plus the decrease in the value of ewes) for a flock of 100 breeding ewes would be $\$ 307.56$, or $\$ 3.08$ per ewe.

\section{RAM REPLACEMENT COST}

Two rams should be maintained for a flock of 50 breeding ewes. It was estimated that each ram would remain in the flock for three breeding seasons. The estimated value of the rams was $\$ 65.00$ each when purchased and $\$ 15.00$ each when sold. The annual replacement cost per breeding ewe was calculated to be 67 cents. $^{9}$

${ }^{7}$ The phenothiazine salt cost was calculated from unit prices itemized in Appendix Table 2.

${ }^{\mathrm{s} D r e n c h i n g}$ cost for ewes, $3 \times 5 \phi=15 \phi$; lambs $2 \times 5 \phi \times 123$ per cent lamb crop $=$ 12.3 $c$. Thus, an average cost of about $28 \phi$ per breeding ewe. The per ewe cost would be higher for the highest income group and lower for the lowest income group due to a difference in the number of lambs.

${ }^{9}$ Ram replacement cost was calculated by the following method: $\$ 65$ minus $\$ 15 \div 3$ years $=\$ 16.66$ annual cost per ram. $\$ 16.66 \div 25$ ewes $=\$ 0.67$ annual cost per ewe. 


\section{MARKETING COST}

The cost for marketing lambs was estimated for those lambs that were sold. The wool marketing cost was deducted at the time of sale and net returns are those presented. An average marketing cost of 50 cents per hundred pounds of lamb was estimated for lambs sold on West Virginia markets. An average of 92 pounds of lamb was marketed per breeding ewe for all flocks in the study. Thus, the cost of marketing 92 pounds of lamb at 50 cents per hundred was about 46 cents per breeding ewe.

\section{PART III: Analysis of Costs and Returns}

In this section the requirement and production items for the sheep enterprise are summarized and prices are attached to each item to determine profitability of the enterprise. However, no attempt is made to place a charge on land, buildings, labor, management, livestock investment, or equipment.

The average receipts and estimated costs per breeding ewe in a 50-ewe flock based on Master Shepherd's Project records and some estimates for the five-year period (1957-1961) are shown in Table 11. The receipts for the 305 flocks in the study averaged $\$ 27.13$ per ewe and the estimated costs averaged $\$ 16.04$. Thus the estimated return to labor, capital and management was $\$ 11.09$ per breeding ewe. The average gross income from all of the ewes included in the study was $\$ 21.60$ from lambs produced and $\$ 3.60$ from the sale of wool. Government incentive payments on wool and unshorn lambs sold added $\$ 1.19$ per breeding ewe for wool sold and 74 cents for the unshorn lambs sold. ${ }^{10}$

The analysis of costs and returns for the flocks in the highest income group is shown in Table 12.

The average gross income from all of the ewes in the highest income group was $\$ 29.19$ from lambs produced and $\$ 3.54$ from the sale of wool. Government incentive payments on the wool and unshorn lambs sold added $\$ 1.19$ per breeding ewe for wool sold and 98 cents for the unshorn lambs sold. The average estimated return per breeding ewe from lambs produced, wool produced, and incentive payments for wool and unshorn lambs was $\$ 34.91$. The total specified costs were $\$ 16.21$ per breeding ewe. The return to labor, capital, and management was $\$ 18.70$ per breeding cwe for the flocks in the highest income group.

${ }^{10}$ The government incentive payment rates of 17 cents per pound for wool sold and 80 cents per 100 lbs. of unshorn lamb sold were obtained at the U.S.D.A. Agricultural Stabilization Service Office, Morgantown, W. Va. 
Costs and Returns Per Breeding Eive in an Average 50-Ewe Flock Based on Master Shepherd's Project Records and Some Estmates for THE FIVE-Year Period, 1957-1961

\begin{tabular}{|c|c|c|c|c|}
\hline \multirow[b]{2}{*}{ ITEM } & \multicolumn{4}{|c|}{ RECEIPTS } \\
\hline & UNIT & QUANTITY & $\begin{array}{c}\text { Per Unit } \\
\text { Price }\end{array}$ & TOTAL \\
\hline Lambs ........ & Lbs. & 108 & $\$ .20$ & $\$ 21.60$ \\
\hline Wool $\ldots \ldots \ldots \ldots \ldots \ldots$ & Lbs. & 7 & .514 & 3.60 \\
\hline Incentive Payment on Wool & Lbs. & 7 & .17 & 1.19 \\
\hline Incentive on Unshorn Lambs & Cwt. & .92 & .80 & .74 \\
\hline Total of Specified Receipts ... & & & & $\$ 27.13$ \\
\hline & & & sts & \\
\hline Hay (Alfalfa) & Ton & .25 & $\$ 33.00$ & 8.25 \\
\hline Concentrate $(\mathrm{mix})^{*}$ & Cwt. & .75 & 2.87 & 2.15 \\
\hline Pheno. Nineral Salt** ...... & Lbs. & 6 & .108 & .65 \\
\hline Medication (drench) ... & - & - & - & .28 \\
\hline Shearing $\ldots \ldots \ldots \ldots \ldots \ldots$ & Ewe & - & - & .50 \\
\hline Ewe Replacement .......... & Ewe & - & - & 3.08 \\
\hline Ram Replacement (per ewe) & & - & - & .67 \\
\hline Mlarketing $\ldots \ldots \ldots \ldots \ldots \ldots$ & Cwt. & .92 & .50 & .46 \\
\hline Total of Specified Cost .. & & & & $\$ 16.04$ \\
\hline
\end{tabular}

Return to Labor, Capital, and Management

$\$ 11.09$

* Three hundred lbs. corn, 200 lbs. oats, 100 lbs. bran, and 50 lbs. soybean oil meal.

**Seven lbs. salt, 7 lbs. steamed bonemeal, and 1 lb. of phenothiazine.

The cost and returns for the flocks in the lowest income group are shown in Table 13.

The average gross income from ewes in the lowest income group was $\$ 12.85$ from lambs produced and $\$ 2.99$ from the sale of wool. Government incentive payments on the wool and unshorn lambs sold added $\$ 1.02$ per breeding ewe for wool sold and 46 cents for the unshorn lambs sold. The average estimated gross returns per breeding ewe from lambs produced, wool produced, and incentive payments for wool and unshorn lambs sold was $\$ 17.32$. The total specified costs were $\$ 15.84$ per breeding ewe. Thus, the return to labor, capital, and management was $\$ 1.48$ per breeding ewe for the flocks in the lowest income group.

\section{SUMMARY, CONCLUSIONS, AND IMPLICATIONS}

This report presents an analysis of data useful in evaluating factors that influence costs and returns for a sheep enterprise in W'est Virginia. The basic data were obtained from Master Shepherd's Project reports and some estimates for the five-year period, 1957 to 1961. The study 


\section{TABLE 12}

Cost and Returns Per Breeding Ewe in 50-Ewe Flock Based on High est Income Group Records from the Master Shepherd's Project Reports and Some Estiniates for the Five-Year Period, 1957-1961

\begin{tabular}{|c|c|c|c|c|}
\hline \multirow[b]{2}{*}{ ITEM } & \multicolumn{4}{|c|}{ RECEIPTS } \\
\hline & UNIT & QUANTITY & $\begin{array}{l}\text { PER Unit } \\
\text { PrICE }\end{array}$ & Total \\
\hline Lambs ...... & Lbs. & 139 & $\$ .210$ & $\$ 29.19$ \\
\hline Wool $\ldots \ldots \ldots \ldots \ldots \ldots \ldots \ldots$ & Lbs. & 7 & .506 & 3.54 \\
\hline Incentive Payment on Wool . & Lbs. & 7 & .17 & 1.19 \\
\hline Incentive on Unshorn Lambs . & Cwt. & 1.22 & .80 & .98 \\
\hline \multirow[t]{2}{*}{ Total of Specified Receipts. } & & & & $\$ 34.91$ \\
\hline & \multicolumn{4}{|c|}{ Costs } \\
\hline Hay (Alfalfa) & Ton & .25 & $\$ 33.00$ & 8.25 \\
\hline Concentrate $(\operatorname{mix})^{*} \ldots \ldots \ldots$ & Cwt. & .75 & 2.87 & 2.15 \\
\hline Pheno. Mineral Salt** ...... & Lbs. & 6 & .108 & .65 \\
\hline Medication (drench) $\ldots \ldots \ldots$ & - & - & - & .30 \\
\hline Shearing $\ldots \ldots \ldots \ldots \ldots \ldots$ & Ewe & - & - & .50 \\
\hline Ewe Replacement ......... & Ewe & - & - & 3.08 \\
\hline Ram Replacement (per ewe). & & - & - & 67 \\
\hline Marketing $\ldots \ldots \ldots \ldots \ldots \ldots$ & Cwt. & 1.22 & .50 & .61 \\
\hline Total of Specified Costs ..... & & & & $\$ 16.21$ \\
\hline \multicolumn{4}{|c|}{ Return to Labor, Capital, and Management } & $\$ 18.70$ \\
\hline
\end{tabular}

*Three hundred lbs. corn, 200 lbs. oats, 100 lbs. bran, and 50 lbs. soybean oil meal. **Seven lbs. salt, 7 lbs. steamed bonemeal, and l lb. of phenothiazine.

encompassed 305 records, or an average of 3,103 breeding ewes and 61 flocks per year. There was an average of 51 breeding ewes per farm flock.

There were 1.25 lambs averaging 86 pounds produced per breeding ewe. Thus, 108 pounds of lamb were produced per breeding ewe. The lambs were sold for an average of 20 cents per pound and returned an average of $\$ 21.60$ per breeding ewe for lambs (see Figure 2). The average fleece weight produced per breeding ewe was 7 pounds, which sold for an average of 51 cents per pound-a return from the sale of wool of $\$ 3.60$ per breeding ewe. The estimated incentive payment of $\$ 1.93$ per ewe for wool and unshorn lambs added to the average wool sales of $\$ 3.60$ gives a total income from wool of $\$ 5.53$ per breeding ewe. Thus, there was a total return of $\$ 27.13$ per breeding ewe, of which $\$ 21.60$ was from lambs and $\$ 5.53$ from wool. The estimated, specified costs per breeding ewe were $\$ 16.05$. The average returns of $\$ 27.13$ per ewe, minus the average estimated costs of $\$ 16.04$ per ewe, left an average return of \$11.09 to labor, capital, and management per breeding ewe. The average return to labor, capital, and management per breeding ewe 
Cost and Returns Per Breeding Eive in 50-Ewe Flock Based on Lowest Income Group Records from the Master Shephern's Project Reports and Some Estimates for the Five-Year Period, 1957-1961

\begin{tabular}{|c|c|c|c|c|}
\hline \multirow[b]{2}{*}{ UNIT } & \multicolumn{4}{|c|}{ RECEIPTS } \\
\hline & UNIT & QUANTITY & $\begin{array}{l}\text { Per Unit } \\
\text { Price }\end{array}$ & TOTAL \\
\hline Lambs ................. & Lbs. & 73 & $\$ .176$ & $\$ 12.85$ \\
\hline Wool $\ldots \ldots \ldots \ldots \ldots \ldots \ldots$ & Lbs. & 6 & .499 & 2.99 \\
\hline Incentive Payment on Wool & Lbs. & 6 & .17 & 1.02 \\
\hline Incentive on Unshorn Lambs . & Cwt. & .58 & .80 & .46 \\
\hline \multirow[t]{2}{*}{ Total of Specified Receipts ... } & & & & $\$ 17.32$ \\
\hline & \multicolumn{4}{|c|}{ Costs } \\
\hline Hay (Alfalfa) & Ton & .25 & $\$ 33.00$ & $\$ 8.25$ \\
\hline Concentrate $(\mathrm{mix})^{*}$ & Cwt. & .75 & 2.87 & 2.15 \\
\hline Pheno. Mineral Salt** ...... & Lbs. & 6 & .108 & .65 \\
\hline Medication (drench) ........ & & - & - & .25 \\
\hline Shearing $\ldots \ldots \ldots \ldots \ldots \ldots$ & Ewe & - & - & .50 \\
\hline Ewe Replacement ......... & Ewe & - & - & 3.08 \\
\hline Ram Replacement (per ewe).. & & - & - & .67 \\
\hline Marketing $\ldots \ldots \ldots \ldots \ldots \ldots$ & Cwt. & .58 & .50 & .29 \\
\hline Total of Specified Costs & & & & $\$ 15.84$ \\
\hline Return to Labor, Capital, & Mal & & & $\$ 1.48$ \\
\hline
\end{tabular}

* Three hundred lbs. corn, 200 lbs. oats, 100 lbs. bran, and 50 lbs. soybean oil mean.

**Seven lbs. salt, 7 lbs. steamed bonemeal, and $1 \mathrm{lb}$. of phenothiazine.

was $\$ 18.70$ for the highest income group and $\$ 1.48$ for the lowest income group.

It was believed that the greater return received by the highest income group relative to the average for all flocks was due to better management practices which resulted in the following:

1. A higher per cent lamb crop marketed (150 per cent compared with 125 per cent).

2. Somewhat heavier lambs at market time (92 pounds compared with 86 pounds).

3. A higher per cent of the lambs marketed being in the Blue grade (86 per cent compared with 70 per cent).

4. Somewhat heavier lambs in the top grades (93 pounds compared with 90 pounds in the Blue grade and 84 pounds compared with 79 pounds in the Red grade) .

5. A higher average price received per pound for lambs (21 cents compared with 20 cents).

6. Higher incentive payments received (\$2.17 compared with \$1.93). 


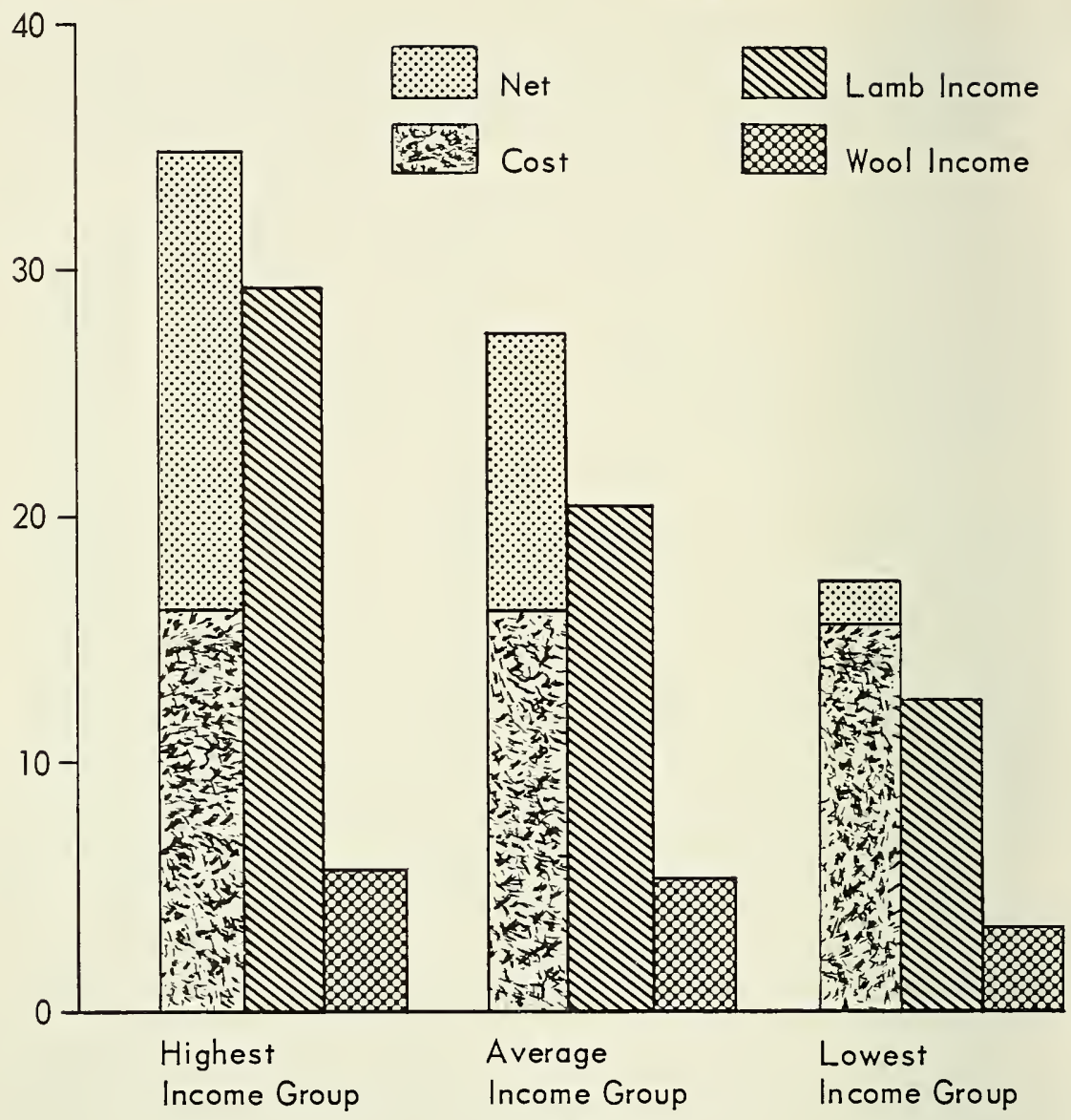

FIGURE 2

The results of this study indicate that a sheep enterprise could yield a sizeable return above specified costs with good management, but returns would be low where management is poor.

Death rates appear to have been a major factor affecting the rate of return from the sheep enterprise. Many deaths could probably be prevented by protecting the flock from dogs and other killers, especially at night, and by giving the animals better care during the winter and lambing season. Perhaps the average weight of lambs sold could be increased by having more of them dropped early in the lambing season, by the selection of larger and better ewes and rams, by following current parasite control recommendations, and by improving pastures. Also, 
more attention to the feeding program in the month prior to lambing should result in stronger lambs and ewes and heavier lambs at market time and a reduction in pregnancy disease. A sheep producer may, by comparing the factors found in this study to be associated with profitability with his recorcls, determine weaknesses in the management of his sheep flock.

\section{BIBLIOGRAPHY}

1. Field Workers' Blue Book, Livestock Program, 1962. "Controlling Internal Parasites in Sheep," Cooperative Extension Service, West Virginia University, Morgantown.

2. Krehbiel, Elmer, 1962. "Acturial Methods Applied to Domestic Animals," Joumal of Animal Science, Vol. 21:973.

3. Livesay, E. A. and Cunningham, C. J., 1957. Native Hampshire Type Ewes vs Western Corriedale Type Ewes, W. Va. Univ Igri. Exp. Sta. Bull. 398. West Virginia University, Morgantown.

4. "Livestock and Poultry Inventory, January I," U.S.D.A., SRS, Crop Reporting Board, Washington, D.C., 1962, 1963, 1964.

5. United States Census of Agriculture, 1959. "Livestock and Livestock Products" Vol. II, General Report, Chap. VI, p. 564, Table 40.

6. West Virginia Agricultural Statistics, 1962. West Virginia Department of Agriculture, Charleston, West Virginia, C. R. Bull., No. 3.

7. Wamsley, B. W., Jr., et al., 1962. Control of Internal Parasites in Sheep, Cooperative Extension Service, Misc. Pub. No. 129, West Virginia University, Morgantown. 

APPENDIX TABLE I

Data Obtained from Master Shepherd's Project Reports and Sumiaries Filed for the Five-Year

Period, 1957 Through 1961

\begin{tabular}{|c|c|c|c|}
\hline & \multicolumn{2}{|c|}{20 Per Cent With } & \multirow{2}{*}{ AlL Flocks } \\
\hline & Highest Incone & LOWEST INCOME & \\
\hline Number of Flocks ....... & 61 & 61 & 305 \\
\hline Number of Breeding Ewes & 2665 & 2938 & 15517 \\
\hline Average Number of Ewes & & & \\
\hline per Flock .......... & 41 & 48 & 51 \\
\hline Number of Lambs Marketed & & & \\
\hline and $\mathbf{K e p t} \ldots \ldots \ldots \ldots$. & 4002 & 2813 & 19366 \\
\hline Average Per Cent Lamb Crop & 150 & 96 & 125 \\
\hline Average Pounds of Lamb & & & \\
\hline per Ewe $\ldots \ldots \ldots \ldots$ & 139 & 73 & 108 \\
\hline Average Weight of Lambs & 92 & 76 & 86 \\
\hline Arerage Price Received per & & & \\
\hline Pound of Lamb ...... & $\$ 0.210$ & $\$ 0.176$ & $\$ 0.200$ \\
\hline Income from Lambs per Ewe .. & $\$ 29.19$ & $\$ 12.85$ & $\$ 21.60$ \\
\hline Per Cent Income from Lambs .. & 89 & 81 & 86 \\
\hline Average Pounds of $\mathrm{W}$ ool & & & \\
\hline per Ewe $\ldots \ldots \ldots \ldots$ & 7 & 6 & 7 \\
\hline Average Price Recejved per & & & \\
\hline Pound of Wool* ......... & $\$ 0.506$ & $\$ 0.199$ & $\$ 0.514 * *$ \\
\hline Income from Wool per Ewe* & $\$ 3.54$ & $\$ 2.99$ & $\$ 3.60$ \\
\hline Per Cent Income from Wool & 11 & 19 & 14 \\
\hline Total Income per Ewe .... & $\$ 32.73$ & $\$ 15.81$ & $\$ 25.20$ \\
\hline
\end{tabular}

* Wool prices do not include govermment incentive payments.

** See footnote 2, Table 9.

APPENDIX TABLE 2

Unit Cost for Feed and Supplies Used to

Determine Costs of Sheep Production

\begin{tabular}{l|c|c}
\hline \hline \multicolumn{1}{c|}{ Item } & Unit & Price \\
\hline Hay $(\text { alfalfa })^{*} \ldots \ldots \ldots \ldots \ldots$ & Ton & $\$ 33.00$ \\
Corn* $\ldots \ldots \ldots \ldots \ldots \ldots \ldots$ & Cwt. & 2.50 \\
Oats* $\ldots \ldots \ldots \ldots \ldots \ldots \ldots \ldots$ & Cwt. & 2.65 \\
Bran* $\ldots \ldots \ldots \ldots \ldots \ldots \ldots$ & Cwt. & 3.40 \\
Soybean Meal** $\ldots \ldots \ldots \ldots$ & Cwt. & 5.00 \\
Salt** $\ldots \ldots \ldots \ldots \ldots \ldots$ & Cwt. & 2.00 \\
Steamed Bonemeal** $\ldots \ldots$ & Cwt. & 7.00 \\
Phenothiazine** $\ldots \ldots \ldots \ldots$ & Lb. & 1.00 \\
\hline
\end{tabular}

* Source of prices, West Virginia Igricultural Statistics, 1960, p. 40. West Virginia Department of Agriculture, Charleston, W. Va. 1963.

**Source of prices, Southeru States Cooperative, Morgantown, W. Va. February, 


